Uploaded : December 2020

Accepted : January 2021

Published : June 2021



\title{
DO FAMILY AND INSTITUTIONAL OWNERSHIPS INFLUENCE THE CORPORATE DIVIDEND POLICY?
}

\author{
Christheana Santoso ${ }^{1}$, Richenda Feily Salim² ${ }^{2}$, Titin Pranoto ${ }^{3}$, Yang Elvi Adelina ${ }^{4}$ \\ ${ }^{1}$ christheana.santoso@student.pmsbe.ac.id, ${ }^{2}$ richenda.salim@student.pmsbe.ac.id, \\ ${ }^{3}$ titin.pranoto@pmbs.ac.id, ${ }^{4}$ yang.elvi@pmbs.ac.id \\ 1,2,3,4Universitas Prasetiya Mulya, Indonesia \\ ${ }^{*}$ corresponding author
}

\begin{abstract}
The difference of interests among shareholders that is dominated by controlling shareholders enlarges the possibility of deprivation towards the minority shareholders' rights. Therefore, a dividend is considered as a tool to reduce conflict of interests between both parties with the assurance of pro-rata distribution of the company's resources. Family and institutional ownerships have unique characteristics that are frequently found in Indonesian firms. Thus, this study intended to analyze the impact of controlling ownership owned by family and institution to dividend policy in nonfinancial firms listed in Bursa Efek Indonesia (BEI) during 2013-2017. The samples are chosen with the purposive sampling method resulting in 373 firms and 1.484 observations obtained. The data used in this study was secondary data from firms' annual and financial reports along with data extracted from Capital IQ. According to the regression results using the fixed-effect model, this study confirms the negative impact of controlling ownership owned by families towards firms' dividend policy. Whilst, controlling ownership owned by institutions shows that it has no significant impact on dividend policy. Otherwise, profitability, size, and leverages are proven to impact firms' dividend policy. However, growth indicates no significant impact.
\end{abstract}

Keywords: Controlling Ownership; Identity; Family Ownership; Institutional Ownership; Dividend Policy.

\begin{abstract}
Abstrak
Perbedaan kepentingan antara pemegang saham di tengah struktur kepemilikan yang didominasi oleh pemegang saham pengendali mampu memperbesar kemungkinan perampasan hak pemegang saham minoritas. Pembagian dividen dianggap dapat menjadi alat untuk meredakan konflik kepentingan antara kedua pihak dengan menjamin pendistribusian yang merata atas sumber daya perusahaan kepada seluruh pemegang saham. Kepemilikan keluarga dan institusi memiliki karakteristik yang unik dan sering ditemukan pada perusahaan di Indonesia. Penelitian ini bertujuan untuk menganalisis pengaruh kepemilikan saham pengendali oleh keluarga dan institusi terhadap kebijakan dividen perusahaan nonkeuangan di Bursa Efek Indonesia (BEI) dalam periode 2013-2017. Pemilihan sampel dilakukan dengan metode purposive sampling dan didapatkan 373 perusahaan dengan 1.484 observasi. Data penelitian merupakan data sekunder yang berasal dari laporan tahunan dan laporan keuangan perusahaan serta basis data elektronik Capital IQ. Berdasarkan hasil regresi menggunakan model fixed effect, hasil penelitian ini membuktikan pengaruh negatif kepemilikan saham pengendali oleh keluarga terhadap kebijakan dividen perusahaan. Sedangkan, kepemilikan saham pengendali oleh institusi didapati tidak mempengaruhi kebijakan dividen. Selain itu, profitabilitas, ukuran dan tingkat hutang perusahaan terbukti mempengaruhi kebijakan dividen.
\end{abstract}


Namun, hasil penelitian ini menemukan pertumbuhan perusahaan tidak berpengaruh signifikan

Kata Kunci: Kepemilikan Saham Pengendali; Identitas; Kepemilikan Keluarga; Kepemilikan Institusi; Kebijakan Dividen.

\section{INTRODUCTION}

The controlling ownership of the public companies is found in Asian countries (Organization for Economic Co-operation and Development [OECD], 2017). Companies in Indonesia usually start with a closed company established by a person or group of individuals. Even though it has developed into a public company, the share ownership structure tends to remain and dominate the company. This causes the controlling ownership structure in Indonesia to be found today (International Finance Corporation, 2018). The controlling ownership is characterized by a number of individuals or groups who own most of the shares and have a strong influence on the company (Dallas, 2004 in Warsini, 2013). Due to its strong influence, the controlling ownership structure as the main or concentrated owner can contribute to oversight of management actions which are often incompatible with the interests of shareholders regarding the management of the company. Thus, this can align conflicts of interest between shareholders and management. However, this condition can also lead to other differences in interests, namely differences in interests between majority and minority shareholders. Majority shareholders can potentially abuse their influence for personal gain that can rob minorities of their rights in the company. This will also be exacerbated by low investor protection and governance problems that often occur in civil law countries, such as in Indonesia (Wardhana \& Tandelilin, 2018).

One of the shareholders' rights is to get a return by their ownership portion. The nature of investors who avoid risk and uncertainty makes the distribution of corporate dividends more desirable than other forms of return (Gordon, 1963). Investors also viewed dividends as favorable considering that they do not always fully understand the intentions of company management (Baker, 2009). Besides, dividends also ensure an even distribution of returns to all shareholders and limit resources in the control of management or majority shareholders (Jensen, 1986; Ramli, 2010). This condition makes dividends an alternative to overcome agency problems that arise between shareholders.

One form of majority share ownership that is often found in Indonesia is family ownership (OECD, 2017). The existence of a family that dominates ownership and control, views the company as a family legacy that must be preserved to be passed on to the next generation. Thus, family influence and company survival must be maintained (Bertrand \& Schoar, 2006). Due to his high involvement in management, the potential for misuse of company resources is even greater. Besides, in countries with weak investor protection, indications of misuse of resources by families can also be reflected in the low dividends distributed (Mulyani, Singh \& Mishra, 2016; Setiawan, Bandhi, Phua \& Trinugroho, 2016). However, this allegation is not limited to indications of misuse of resources. The risk-averse nature of the family can also make the family keep the cash they have so that it can reduce the company's dividend payments (Smirnova, Tabriztchi 
\& Lange, 2015).

Meanwhile, institutional shareholders engaged in the financial sector have a strong supervisory nature because of their expertise in evaluating financial performance, management quality, and corporate governance (Crane, Michenaud \& Weston, 2016). Financial institutions are usually also intermediaries responsible for other parties' funds (Scholtens \& Van Wensveen, 2000, in Ducassy \& Montandrau, 2015). Thus, the supervisory role of institutional owners on management may affect the company's dividend policy and reduce agency conflicts (Chang, Kang \& Li, 2016; Crane et al., 2016). However, with a high supervisory role, institutional owners can also directly reduce agency problems and reduce the urgency to pay dividends (Bushra \& Mirza, 2015; Kautsar, 2019).

The results of this research are quite diverse and the existence of controlling share ownership by families and institutions that is commonly found makes this study aim to further analyze the effect on dividend policy of public companies in Indonesia. Amid a country with weak investor protection and the presence of high majority shareholdings, the results of this study are expected to contribute to increasing regulator awareness of the importance of regulations regarding information disclosure and transparency of public companies, especially concerning the use of retained earnings and dividend policies. This study also contributes to the renewal of the period of the study sample compared to existing previous studies.

\section{LITERATURE REVIEW}

\section{Agency Theory}

An agency relationship is a contract between the principal as the owner and the agent, where the agent is hired to act on behalf of the principal and is given authority and authority regarding decision making in the company (Jensen \& Meckling, 1976). However, there are often differences in interests between company owners and management or it can be classified as a type 1 agency problem. Then, Jensen and Meckling (1976) state that the agency relationship in a company is not limited to owner and management only, especially when the company sells a portion of its ownership. to the other party. This will create differences in interests between the majority shareholder (the main owner of the company) and other parties or minority shareholders.

The majority shareholder has the potential to use the company's resources for personal gain with the majority of control still owned as a result of reduced share ownership due to the presence of minority shareholders (Jensen \& Meckling, 1976). The existence of several new owners makes company profits must be distributed based on the portion of ownership. It can also make the majority shareholder reluctant to contribute more because it is considered that the return cannot be proportional to the effort made to the company (Jensen \& Meckling, 1976). This problem or hereinafter classified as a type 2 agency problem, makes minority shareholders want supervision of the behavior of the majority shareholder. 


\section{Bird in Hand Theory}

The Bird in Hand theory is a theory coined by Gordon (1963). This theory states that amidst market imperfections and information asymmetry, dividends are a relevant policy for increasing share prices and firm value. According to this theory, investors choose definite returns such as dividend payments due to the nature of investors who tend to avoid risk and uncertainty (Gordon, 1963). The higher the current dividend payment, the lower the risk level and the uncertainty of the company's cash flow. This causes investors to prefer dividends over other forms of return such as capital gains (Oktaviani \& Desmintari, 2016). This is because capital gains are closely related to stock prices which always change over time. Therefore, returns in the form of dividends are better (bird in hand) than retained earnings (a bird in the bush), because the profits cannot be realized in the future (can fly away) (La Porta et al., 2000).

\section{Ownership Structure}

Ownership structures can be categorized into two types, namely distributed ownership and concentrated ownership. Distributed ownership is characterized by relatively small share ownership of the company by many shareholders so that control over the company is centered on professional management (Barclay \& Holderness, 1989; Claessens, Djankov \& Lang, 2000). Meanwhile, concentrated ownership is characterized by the existence of shareholders with controlling ownership in the company (Barclay \& Holderness, 1989). In modern companies, the spread ownership structure in the company is expected to increase (Claessens et al., 2000). But in reality, there is still much-concentrated ownership due to weak protection of shareholder rights, especially in Asian countries (OECD, 2017).

The majority shareholders in a concentrated ownership structure can incur costs to supervise and discipline managers, so that type 1 agency problems can be minimized (Shleifer \& Vishny, 1986). In contrast to the majority shareholder, minority shareholders require heavier efforts to exercise supervision given the lower returns they get (Shleifer \& Vishny, 1997). This can cause majority shareholders to abuse their influence and prioritize their interests which may not be in line with the interests of other shareholders in the company (Shleifer \& Vishny, 1997). One example of abuse of the influence of the majority shareholder is the transfer of company resources to its affiliates through related party transactions (Setiawan et al., 2016). This of course can harm minority shareholders.

In addition to the large proportion of ownership, the majority share ownership structure can be grouped according to their identity (Aluchna et al., 2019; Thomsen \& Pedersen, 2000). Different motivations and perspectives of shareholders can be reflected in the company's strategy in determining profit targets, dividends, capital structure, or growth rates. Therefore, this study discusses more deeply about the majority share ownership with family and institutional identities.

\section{Controlling Share Ownership by Family}

Family ownership is ownership by the founder and his family members of the company, either directly or through affiliated companies (Mulyani et al., 2016). 
Various studies define majority share ownership by a family that can effectively control a company if it owns at least 20\% of its shares (Darmadi, 2016; Mulyani et al., 2016). According to Bertrand and Schoar (2006), the family as the founder of the company has a long-term commitment to maintaining and maintaining the survival of the company. The company is a family legacy that must be preserved and passed on to the next generations, hence the influence and control of the family over the company must be preserved. This commitment is a form of socioemotional wealth. In other words, social wealth is another goal in the form of values and obligations that the family must achieve in the company in addition to financial goals (Bertrand \& Schoar, 2006). Family values in the company often make the family avoid decisions that risk-reducing its influence on the company. Also, family owners have the potential to engage in nepotism such as giving positions to family members in company management rather than recruiting professional managers who come from external parties (Bertrand \& Schoar, 2006; Duygun, Guney \& Moin, 2018).

From agency theory, the presence of family ownership in the company can create an alignment of interests between family shareholders and managers (alignment effect) (Mulyani et al., 2016). This is because family shareholders often have a dual role as owner and manager of the company (Thomsen \& Pedersen, 2000). However, the close relationship between family shareholders and management will also make it easier for family shareholders to access company resources (Al-Najjar \& Kilincarslan, 2016). This condition increases the potential for the majority shareholder of the family to act according to their interests (entrenchment effect) and creates agency problems with minority shareholders (Mulyani et al., 2016).

\section{Controlling Share Ownership by Institutional}

The controlling ownership owned by institutions is ownership by financial institutions such as banks, insurance companies, investments, and pension funds (Miko \& Kamardin, 2015; Renneboog \& Szilagy, 2015). Institutional ownership in a company can be said to be large or the majority of institutional shareholders own at least $5 \%$ of the company's shares ( $\mathrm{Lin} \& \mathrm{Fu}, 2017$ ). The supervisory role that institutional shareholders have is based on their ability to evaluate financial performance, management quality, and also corporate governance (Crane et al., 2016). This is also motivated by financial success because financial institutions are intermediary agents for the real owners of funds. Thus, the objective of financial institutions will be more towards the liquidity and economic benefits of the companies they invest in (Thomsen \& Pedersen, 2000). Apart from being an intermediary agent, shareholders of financial institutions usually have a substantial percentage of equity ownership in the company. Thus, institutional investors do not have the same abilities as individual investors who can liquidate their ownership without affecting share prices (Musallam, Fauzi \& Nagu, 2019). Therefore, institutional shareholders will tend to exercise the active supervision of the companies they invest in.

However, institutions that own the controlling share ownership give them access to company personal information that may be misused for their gain and reduce the company's need for capital markets as an external surveillance system 
(Velury \& Jenkins, 2006; Al-Najjar, 2010). This condition can shift active surveillance to exploitation for personal gain or exploitation view (Velury \& Jenkins, 2006). However, shareholders of financial institutions can also exercise passive supervision. This results in institutional shareholders not interfering in management and buying and selling shares only to get short-term profits, by taking advantage of their advantages in obtaining company information (Lin \& Fu, 2017).

\section{Dividend}

Dividends are payments on company profits directly to shareholders for their contribution in financing the company's finances (Ross, Westerfield, Jordan, Lim \& Tan, 2016; Reyna, 2017). Law Number 40 of 2007 regarding Limited Liability Companies, in article 71 paragraph 2 states that the dividends distributed are the entire net profit that has been reduced by the allowance for reserves unless otherwise stipulated in the GMS. The regulation also states that the condition for companies to pay dividends is to have positive retained earnings. Although important because it can indicate company performance and increase shareholder value, dividends also reduce internal funds (Sindhu, Hashmi \& Ul Haq, 2016). By paying dividends, the company's opportunity to finance investment can be reduced. Conversely, a reduction in dividends paid can be viewed as a sign the company is experiencing financial difficulties. Therefore, dividend policy is quite crucial for the company (Reyna, 2017).

From agency theory, dividends are often used as an alternative to alleviate the problem of differences of interest (Easterbrook, 1984; Jensen, 1986; Rozeff, 1982). In type 1 agencies, dividend payments can reduce resources under management control thereby reducing the potential for misuse of company resources. Also, dividend distribution can encourage companies to take external funding to fund their operations. At the same time, dividend payments will expose management to the oversight of the funder (Easterbrook, 1984). Besides, in the type 2 agency problem, dividend distribution can ensure an even distribution of cash flow for all shareholders and limit the control of large shareholders over company resources (Ramli, 2010).

\section{The Effect of Controlling Share Ownership by Family on Dividend Policy}

The high dividend payments of the company amidst the majority share ownership by the family can be explained in two ways (Isakov \& Weisskopf, 2015). First, dividend payments are used to build a company's reputation when the company needs external funding. Then, the family also increases dividend payments to fund their consumption. The dividend payment is a way to diversify family assets that are embedded in the company and an effort to avoid selling shares that can reduce the family's influence on the company.

However, various studies have also found that the controlling share ownership by families in companies tends to reduce dividend payments. Mulyani et al. (2016) stated that Indonesia is a civil law country, where the level of protection for shareholders is quite weak. Family owners also tend to choose company management based on family relationships. Subsequently, in Indonesia, controlling share owners often placed their family members in company's top 
management position (Santos, Rindra, Hidayat \& Adelina, 2020). This condition causes the family to easily accumulate cash under their power, making it vulnerable to misuse for personal purposes. As a result, dividend payments in family companies will be lower (Mulyani et al., 2016; Setia Atmaja, 2016; Setiawan et al., 2016). In addition, Smirnova et al. (2015) stated that families also tend to maintain their internal funds as a form of financial strategy. Families prefer to invest their retained earnings to maintain the sustainability and reputation of the company for future generations (Djebali \& Belanes, 2015). This is related to another motivation of the family, namely maintaining its influence and maintaining the family heritage.

To maintain the sustainability of the company, family owners tend to maintain adequate internal funds to avoid risks, such as the risk of bankruptcy or cash shortages. Then, these funds can also potentially be allocated to support the sustainability and reputation of the company in the future. However, strong family influence also has the potential to be misused for personal gain. Moreover, in a country with low investor protection such as Indonesia, the conflict between majority and minority shareholders is very likely to occur. This condition allows for the deprivation of the rights of minority shareholders by the majority of family shareholders in terms of profits distributed as dividends,

Moreover, in the case of Indonesia, company with family ownerships tend to go with Asian values of family loyalties (Duygun, Guney \& Moin, 2018). Under family control, managers can use investments in company and act to maximize the family's wealth to the extend of detriment of the minority shareholders' rights. Therefore, such companies tend to pay less dividends. Thus, the formulation of the hypothesis of this study is as follows.

\section{H1: The controlling share ownership by the family has a negative effect on dividend policy.}

\section{The Effect of Controlling Share Ownership by Institution on Dividend Policy}

The ability of institutional owners to supervise company management to provide good performance and act in the interests of shareholders can reduce agency problems (Jensen, 1986; Easterbrook, 1984). The significant influence of institutional owners in a company can arise because of their responsibility as intermediaries for the actual owners of funds (Zeckhauser \& Pound, 1990; Thomsen \& Pedersen, 2000). This makes the majority shareholder of the institution exercises active supervision of the companies they invest in. Although institutions can also perform passive surveillance, Crane et al. (2016) argue that institutions also have a role in company supervision. Meanwhile in Indonesia, the active role of majority institutional shareholders is manifested by exercising their voting rights, providing advice on company strategy, and reminding the external risks of their investment companies that may occur (IFC, 2018). Seeing this, the presence of majority share ownership by institutions is seen as capable of influencing company policy, such as dividend policy (Al-Najjar \& Belghitar, 2014).

The ability of controlling institutional shareholders to improve the company's dividend policy is also supported by several studies such as Chang et al. (2016); Aluchna et al. (2019); Sindhu et al. (2016); Renneboog and Szilagyi (2015) 
who found that institutional shareholders can reduce agency problems by using dividends as a monitoring tool. The presence of institutional shareholders in the company can change management attitudes with their expertise in the financial sector so that companies avoid opportunistic behavior and can protect minority shareholders with dividend payments (Miko \& Kamardin, 2015; Djebali \& Belanes, 2015; Sindhu et al., 2016). However, some studies have found the opposite relationship. Namely, the strong role of supervision by institutional shareholders of the company can simultaneously reduce agency problems, thereby minimizing the need to pay dividends (Kautsar, 2019).

In Indonesia, the existence of financial institutions is considered quite important in maintaining financial stability, monetary stability, and capital market development (IFC, 2018). Therefore, financial institutions are institutions that are strictly regulated by the government and are faced with certain prerequisites to mitigate the risk of failure of the institution. This can make financial institutions prudent in investing. Also, tight regulations can prevent financial institutions from doing things that only benefit themselves and encourage institutions to side with the interests of minority shareholders. Thus, the company's dividend payment can increase. This is supported by the research of Truong and Heaney (2007, in Aluchna et al., 2019) which found that among other majority shareholders, financial institutions have the least participation in the abuse of company policy through dividends. Therefore, financial institutions can mitigate agency conflicts and actively demand shareholder policies (Aluchna et al., 2019). This realizes the research hypothesis as follows.

\section{H2: The controlling share ownership by the institution has a positive effect on dividend policy.}

\section{Research Frameworks}

Picture 1 is the research framework used in this study based on the hypotheses.

Picture 1. Research Framework

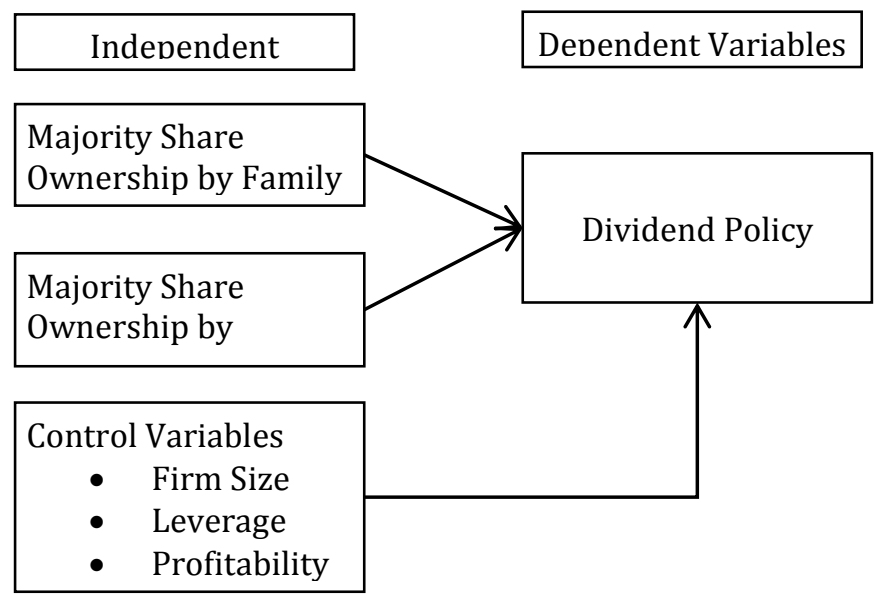

Source: Processed data (2020) 


\section{RESEARCH METHODOLOGY}

\section{Sample and Population}

The population of data used in the study was non-financial companies listed on the Indonesia Stock Exchange (IDX) from 2013 to 2017. The research sample was taken by purposive sampling technique, where sampling was carried out based on certain criteria. Moreover, this research utilized the model of the unbalanced panel data. The list of samples can be described in the Table 1 .

Table 1. Research Samples

\begin{tabular}{lcc}
\hline \multicolumn{1}{c}{ Sample Selection Criteria } & $\begin{array}{c}\text { Number of } \\
\text { Companies }\end{array}$ & $\begin{array}{c}\text { Number of } \\
\text { Observation }\end{array}$ \\
\hline Companies listed on the IDX in 2013-2017 & 558 & 2.790 \\
Companies engaged in the financial industry & $(100)$ & $(500)$ \\
Companies that have negative retained earnings & & $(549)$ \\
Companies with incomplete financial data & & $(257)$ \\
Companies selected as samples & $\mathbf{3 7 3}$ & $\mathbf{1 . 4 8 4}$ \\
\hline
\end{tabular}

Source: Processed data (2020)

\section{Operationalization of Variable}

Below is the table of operationalization of variables used in this study. It consists of one dependent variable, two independent variables, and four control variables.

Table 2. Operationalization of Variable

\begin{tabular}{|c|c|c|}
\hline Variable & Proxy & Formula \\
\hline Dividend Policy (DIV) & Dividend Yield & $\begin{array}{l}\text { DIV = Cash dividend per share paid in the } \\
\text { following year / Price per share at the } \\
\text { end of the current year }\end{array}$ \\
\hline Controlling Share & & FAM = dummy of family share ownership \\
\hline $\begin{array}{l}\text { Ownership by Family } \\
\text { (FAM) }\end{array}$ & Dummy & $\begin{array}{l}\text { percentage } \\
\geq 20 \% \text {. }^{\prime}{ }^{\prime}=\text { Yes, ' } 0 \text { ' = No }\end{array}$ \\
\hline Controlling Share & & INS = dummy of institutions share \\
\hline Ownership by & Dummy & ownership \\
\hline Institution (INST) & & percentage $\geq 5 \%$. ' 1 ' = Yes, ' 0 ' = No. \\
\hline Size (SIZE) & Total Asset & SIZE $=\log ($ Total Asset $)$ \\
\hline Leverage (LEV) & Debt to Asset & LEV $=$ Total Debt/Total Asset \\
\hline Profitability (ROA) & Return on Asset & ROA $=$ Net Income $/$ Total Asset \\
\hline Growth (GROWTH) & $\begin{array}{l}\text { Average company } \\
\text { growth in } 3 \text { years }\end{array}$ & $\operatorname{GROWTH}_{1)}=($ Sales $(\mathrm{t})-$ Sales $(\mathrm{t}-1)) /$ Sales $(\mathrm{t}-$ \\
\hline
\end{tabular}

Source: Processed data (2020)

In this study, measurement of share ownership percentage owned by family is counted by accumulating direct ownership by individual family or familyaffiliated company. According to La Porta at al. (1999), family with at least $20 \%$ of share ownership is capable of effectively controlling a company. If a company is founded by more than one family, each family has to possess at least $20 \%$ of the company's share. This study limits the identification of family ownership to first and second generation. First generation includes the founder, the founder's spouse, and the founder's siblings. Further, second generation includes the 
founder's children and the founder's children-in-law (Hiebl, 2015; Xu et al., 2015). Withal, the ownership by non-public company will also be investigated further. However, if ownership information regarding said company cannot be found, this study will consider it as a family company (Darmadi, 2016; Faccio \& Lang, 2002; Maury, 2006). Ergo, if the company fulfil the criteria above, it is given a value of 1 for the variable of FAM. Otherwise, it is given the value of 0 .

Subsequently, companies that are categorized into a financial institution are bank, insurance company, pension fund company, investment company and or other financial institutions. 5\% or more share ownership by institutional company means that those institutional companies are the majority share owner (Bhojraj \& Sengupta, 2003; Lin \& Fu, 2017). Moreover, Moin et al. (2019) showed that during the year of 1995-2014, the average percentage of institutional ownerships in Indonesia is relatively low. The smallest share ownership by institutional company is $0.37 \%$ and the largest one is $13 \%$. Thusfar, based on those previous studies, the minimum value of $5 \%$ share ownership is relevant to show that an institution company is one of the controlling owners. Hence, if the company fulfil the criteria above, it is given a value of 1 for the variable of INST. Otherwise, it is given the value of 0 .

\section{Data Analysis Method}

In analyzing the data, this study conducted a descriptive statistical test to describe the central tendency and the distribution of data. Furthermore, the analysis conducted the Chow test, Hausman test, and the Lagrange Multiplier (LM) test. Then, this study conducted a classical assumption test to fulfill the Best Linear Unbiased Estimator (BLUE) assumption in the linear regression model. This test includes the normality, multicollinearity, heteroscedasticity, and autocorrelation tests. Finally, this study conducted a hypothesis test consisting of the coefficient of determination, $\mathrm{t}$ statistical test, F-statistic test, homogeneity test, and independent t-test.

\section{Research Model}

To examine the effect of majority share ownership by families institutions on dividend policy, this study uses a multiple linear regression model as described in Formulae 1.

$$
\begin{gathered}
\text { Formula 1. Statistical Model } \\
\text { DIVit }=\beta_{0}+\beta_{1} F A M_{i t}+\beta_{2} I N S T_{i t}+\beta_{3} R O A_{i t}+\beta_{4} S I Z E_{i t}+\beta_{5} L E V_{i t}+\beta_{6} G R O W T H_{i t}+\varepsilon_{i t}
\end{gathered}
$$

\section{RESULT AND DISCUSSIONS}

\section{Descriptive Statistics}

Table 3 shows the results of descriptive statistics with a total of 1,484 observations. The average company pays a cash dividend is $1.69 \%$ relative to its share price. The highest dividend yield value reached $33.02 \%$ in 2017 . In addition, since the controlling share ownership by families (FAM) and institutions (INST) both use dummy variables, thus the minimum and maximum values are 0 and 1 . FAM and INST show mean values of 0.73 and 0.26 , respectively. This indicates that 
from all research observations, there are $73 \%$ of companies whose ownership is majority-owned by families and only $26 \%$ of companies with institutions as a major owner.

Table 3. Descriptive Statistics Result

\begin{tabular}{ccccc}
\hline Variable & Mean & Std. dev & Min & Max \\
\hline DIV & 1,69 & 2,76 & 0,00 & 33,02 \\
FAM & 0,73 & 0,44 & 0,00 & 1,00 \\
INST & 0,26 & 0,44 & 0,00 & 1,00 \\
ROA & 5,56 & 8,15 & $-52,54$ & 71,60 \\
SIZE & 28,79 & 1,55 & 23,56 & 33,33 \\
LEV & 23,59 & 17,98 & 0,00 & 81,05 \\
GROWTH & 47,51 & 603,02 & $-283,65$ & $15.914,10$ \\
\hline
\end{tabular}

Note:

DIV= Dividend policy (\%); FAM= Majority share ownership by family (dummy); INST=

Majority share ownership by institution (dummy); ROA= Profitability (\%); SIZE= Size (logarithm); LEV= Leverage (\%); GROWTH= Growth (\%).

Source: processed data (2020)

Furthermore, to fulfill the normality assumption, the study conducted the winsorize treatment to normalize the data for several variables including dividend policy (DIV), company profitability (ROA), and company growth (GROWTH). This impacts the adjustment of the descriptive statistics, especially related to data standard deviation.

\section{Pearson Correlation Test Result}

The Pearson correlation test results show that all coefficients do not exceed 0.8 so that the research model is free from multicollinearity. The correlation test also shows that all independent variables have a significant correlation at a $1 \%$ level with the dependent variable. The correlation coefficient of controlling share ownership by family and institution variables, leverage, and company growth shows a negative direction indicating the potential to reduce company dividend payments. Meanwhile, the positive correlation coefficient between the profitability and company size variable on dividend policy shows its potential in increasing the level of company dividend payments.

Table 4. Pearson Correlation Test Result

\begin{tabular}{|c|c|c|c|c|c|c|c|}
\hline & DIV & FAM & INST & ROA & SIZE & LEV & GROWTH \\
\hline DIV & 1,0000 & & & & & & \\
\hline FAM & $-0,0859 * * *$ & 1,0000 & & & & & \\
\hline INST & $-0,0652^{* * *}$ & $-0,0559 * * *$ & 1,0000 & & & & \\
\hline ROA & $0,3628^{* * *}$ & $-0,1037^{* * *}$ & $-0,0990^{* * *}$ & 1,0000 & & & \\
\hline SIZE & $0,0881^{* * *}$ & $-0,1886^{* * *}$ & $-0,0675^{* * *}$ & $0,0786^{* * *}$ & 1,0000 & & \\
\hline LEV & $-0,1676^{* * *}$ & $0,1630^{* * *}$ & 0,0036 & $-0,3620^{* * *}$ & $0,2432^{* * *}$ & 1,0000 & \\
\hline GROWTH & $-0,1015^{* * *}$ & $0,0539 * * *$ & 0,0292 & $0,1726^{* * *}$ & 0,0104 & $0,0630^{* * *}$ & 1,0000 \\
\hline
\end{tabular}

$* * *=1 \%$-significance level; ${ }^{* *}=5 \%$-significance level; ${ }^{*}=10 \%$-significance level; DIV= Dividend policy; FAM= Majority share ownership by family; INST = Majority share ownership by institution; ROA= Profitability; SIZE= Size; LEV= Leverage; GROWTH= Growth.

Source: processed data (2020) 


\section{Regression Result}

Before running the regression test on the data, model selection test and classical assumptions test were utilized. There are four tests carried out following the fulfillment of classical assumption criteria. Moreover, based on the results of model selection test, this study uses the FE (Fixed-Effect) model because it is the most appropriate model compared to the other models.

Table 5. Hypothesis Test Result

\begin{tabular}{ccll}
\hline Variable & Coefficients & \multicolumn{1}{c}{$\mathbf{P}>|\mathbf{t}|$} & \multicolumn{1}{c}{ Result } \\
\hline FAM & $-0,4694$ & $0,042^{* *}$ & Significantly Negative \\
INST & $-0,2102$ & 0,142 & Insignificant \\
ROA & 0,0851 & $0,001^{* * *}$ & Significantly Positive \\
SIZE & 0,9134 & $0,001^{* * *}$ & Significantly Positive \\
LEV & $-0,2161$ & $0004^{* * *}$ & Significantly Negative \\
GROWTH & $-0,0039$ & 0,134 & Insignificant \\
CONS & $-24,2010$ & & $0,001^{* * *}$ \\
\hline
\end{tabular}

\begin{tabular}{cr}
\hline Coefficient of & $8,12 \%$ \\
Determination $\left(\mathrm{R}^{2}\right)$ & 0,0009 \\
Prob $>$ F &
\end{tabular}

${ }^{* * *}=1 \%$-significance level; ${ }^{* *}=5 \%$-significance level; ${ }^{*}=10 \%$-significance level; FAM= Majority share ownership by family; INST= Majority share ownership by institution; ROA= Profitability; SIZE= Size; LEV= Leverage; GROWTH= Growth.

Source: processed data (2020)

Based on Table 5, the regression results show a determination coefficient of $8.12 \%$. This number indicates that the independent variable of the study only explains the company's dividend policy by $8.12 \%$. The study conducted hierarchical regression to determine the contributions of each independent variable. Subsequently, based on the hierarchical regression result on Table 6 , the study found that the variable controlling share ownership by families and institutions only contributed $0.27 \%$ in explaining dividend policy.

Table 6. Hierarchical Regression Result

\begin{tabular}{cccccc}
\hline DIV & $\begin{array}{c}\text { Without Control } \\
\text { Variable }\end{array}$ & $\begin{array}{c}\text { 1 Control } \\
\text { Variable }\end{array}$ & $\begin{array}{c}\text { 2 Control } \\
\text { Variable }\end{array}$ & $\begin{array}{c}\text { 3 Control } \\
\text { Variable }\end{array}$ & $\begin{array}{c}\text { 4 Control } \\
\text { Variable }\end{array}$ \\
\hline FAM & $-0,340^{*}$ & $-0,437^{* *}$ & $-0,441^{* *}$ & $-0,454^{* *}$ & $-0,470^{* *}$ \\
INST & $-0,264$ & $-0,235$ & $-0,229$ & $-0,204$ & $-0,210$ \\
ROA & & $0,082^{* * *}$ & $0,087^{* * *}$ & $0,079^{* * *}$ & $0,085^{* * *}$ \\
SIZE & & & $0,807^{* * *}$ & $0,970^{* * *}$ & $0,913^{* * *}$ \\
LEV & & & & $-0,024^{* * *}$ & $-0,022^{* * *}$ \\
GROWTH & & & & & 0,004 \\
Cons & $1,907^{* * *}$ & $1,531^{* * *}$ & $-21,721^{* * *}$ & $-25,811^{* * *}$ & $-24,201^{* * *}$ \\
R2 & $0,27 \%$ & $5,55 \%$ & $7,05 \%$ & $7,94 \%$ & $8,12 \%$ \\
Prob $>$ F & 0,177 & 0,000 & 0,001 & 0,001 & 0,001 \\
\hline
\end{tabular}

${ }^{* * *}=1 \%$-significance level; ${ }^{* *}=5 \%$-significance level; ${ }^{*}=10 \%$-significance level; FAM= Majority share ownership by family; INST= Majority share ownership by institution; ROA= Profitability; SIZE= Size; LEV= Leverage; GROWTH= Growth.

Source: processed data (2020)

Meanwhile, the variable that shows the largest contribution in explaining dividend policy is the financial performance factor, namely profitability. Although the variable controlling share ownership structure also influences dividend policy, 
a greater contribution in explaining dividends is found in factors directly related to company performance. However, the F significance test result shows a Prob $>F$ value of 0.0009 which indicates rejection of the null hypothesis (H0). Thus, the research model is suitable (fit) to explain the effect of the independent variable on the dependent variable simultaneously.

\section{Test Results}

The test results showed in Table 5 prove the effect of family ownership on company policy. The 5\%-significance level can be due to the condition of companies in Indonesia that are majority-owned by families (IFC, 2018). The low dividend distribution in family controlling ownership can indicate two different things, namely the potential for the family to misuse company resources or the family shareholders to reinvest the profits earned.

According to La Porta et al. (2000) and Thomsen and Pedersen (2000), families as controlling owner can handle management and its decisions well. Moreover, the dual role of the family as owner and manager can ease their access to management, which is often found in companies in Indonesia. However, the size of the ownership and dual roles make family shareholders able to abuse company resources and maximize personal gain. Weak investor protection and low information disclosure can also increase the potential for misuse of resources by the majority shareholder (Mulyani et al., 2016). Therefore, a company where one of the majority shareholders is a family is considered able to tunnel or transfer cash flow, profits, or company assets to their families directly or through affiliated companies (Madhani, 2016; Setiawan et al., 2016). By doing this, company funds or resources that should be able to be distributed as dividends can decrease significantly (Mulyani et al., 2016; Setia Atmaja, 2016; Setiawan et al., 2016). Thus, minority shareholders in the company have the potential to suffer losses due to not receiving the rate of return they should have.

In addition to the potential for misuse of resources, the low dividend payout in majority family ownership can also be caused by other family motivations besides the company's financial goals. Families tend to maintain their influence in the company and ensure the continuity of the family company to be passed on to the next generation (Bertrand \& Schoar, 2006; Vandemaele \& Vancauteren, 2013). Given the family's goals, adequate internal funds are important and are considered to be able to prevent the company from going bankrupt and provide reserves for the company's operational needs (Duran, Lozano, \& Yaman, 2016). The family also chooses to reinvest its cash flow and profits because it can support the company's future profits and maintain the sustainability and reputation of the family compared to increasing dividend payments (Djebali \& Belanes, 2015). This practice can also lead to reduced dividends distributed by the company.

This result is also supported by a mean difference test done in comparing the mean of two different classes of family ownership on dividend policy. Dividend payment differences between groups were also found to be significant at the 1\% level. Based on table 9, it is found that, on average, companies without controlling ownership by the family distribute greater dividends than companies where one of the controlling ownership is family. Difference test' results on the company's performance factor also show why family majority-owned companies distribute 
lower levels of dividends. Different test results show that companies without a family as the controlling ownership tend to have higher profitability and company size as well as lower levels of debt and company growth than companies whose ownership is dominated by family. The performance of a company whose controlling ownership are not owned by the family is more likely to be able to distribute dividends. The result of the different tests is as follows.

Table 7. Difference Test of Family Ownership Group

\begin{tabular}{cccc}
\hline Variable & $\begin{array}{c}\text { Companies without } \\
\text { family as major } \\
\text { shareholder } \\
\text { (394 observations) }\end{array}$ & $\begin{array}{c}\text { Mean } \\
\text { Companies with } \\
\text { family as major } \\
\text { shareholder (1.090 } \\
\text { observations) }\end{array}$ & $\operatorname{Pr}(|\mathbf{T}|>|\mathbf{t}|)$ \\
\hline DIV & 1,9000 & 1,4700 & $0,0016^{* * *}$ \\
ROA & 6,5873 & 4,9462 & $0,0005^{* * *}$ \\
SIZE & 29,2731 & 28,6129 & $0,0000^{* * *}$ \\
LEV & 18,7133 & 25,3469 & $0,0000^{* * *}$ \\
GROWTH & 12,04122 & 14,8903 & $0,0379^{* *}$ \\
\hline
\end{tabular}

DIV= Dividend policy; FAM = Majority share ownership by family; INST= Majority share ownership by institution; ROA= Profitability; SIZE= Size; LEV= Leverage; GROWTH= Growth.

Source: processed data (2020)

In contrast to family ownership, the controlling share ownership by institutions is not proven to affect the company's dividend policy. This study found that only $26 \%$ of Indonesian companies are majority-owned by financial institutions. Thus, the supervisory role exercised by institutional shareholders doesn't likely influence companies' decisions. Furthermore, this confirms the findings of Sinarmayarani and Suwitho (2016) which state that institutional shareholders are found not to supervise management effectively. Additionally, this study also found that financial institutions in Indonesia have more potential to conduct passive supervision. This can be the reason for the lacking influence of institutions on dividend policy because of the nature of the passive supervision carried out, which usually means that institutions do not involve themselves in company management policies (Lin \& Fu, 2017).

Other factors that affect the company's dividend policy are the company's profitability, size, and level of debt. Profitability describes the level of company profit. The higher the profitability of a company, the easier it is to pay returns to shareholders in the form of dividends (Bushra \& Mirza, 2015; Chang et al., 2016). Company size has also been shown to increase dividend payments due to the easier access for companies to make funding in the capital market. This causes a reduction in the level of the company's dependence on internal funds so that the company does not have obstacles to pay dividends (Kisman, 2013). Meanwhile, the level of debt has a negative effect on dividend policy because the company's internal fund adequacy will prioritize paying off its financial obligations first. However, company growth was found to be insignificant in this study. 


\section{CONCLUSION}

This study aims to analyze the effect of controlling share ownership by families and institutions on company dividend policy. The results showed that the controlling share ownership by the family had an effect on the low dividends distributed. Companies with a majority of family ownership have the potential to misuse company resources for personal gain so that the resources that can be distributed as dividends are reduced. Furthermore, the weak protection of investors in Indonesia also increases the likelihood of deprivation of minority shareholders' rights. However, the reduction in dividend payments can also be due to the tendency of families to choose to reinvest their profits to support the sustainability of the company in the future. On the other hand, this study found that the controlling share ownership by institutions does not affect dividend policy. This lack of influence can be caused by the low presence of shareholders of financial institutions in public companies in Indonesia. Institutional shareholders in Indonesia can also have the potential to exercise passive supervision so that institutional shareholders become less involved in company management policies. Other factors such as profitability, size, and level of corporate debt also influence the company's dividend policy. However, company growth does not affect the company's dividend payments.

This research is also inseparable from several limitations. First, identification of family ownership is carried out based on judgments that can lead to subjective assessment results. The existence of limited official information for some sample companies can affect the classification of companies with the family's controlling share ownership. Then, this study cannot confirm the cause of the minimum dividend distribution in companies where one of the owners of the controlling share has a family identity. Research cannot distinguish whether families abuse resources or whether there is a preference for families who choose to reinvest their profits instead of paying dividends. This study also found that controlling share ownership by families and institutions made a small contribution in explaining dividends compared to company performance variables. Based on existing limitations, further research can add other factors that can strengthen indications of misuse of company resources, such as differences in control rights and cash-flow rights. Subsequent research can also add analysis related to other corporate governance and performance factors to further explain the company's dividend policy. Then, research can also be done specifically in financial companies. Furthermore, the next research can consider the addition of other dependent variables to see the difference in the influence between the controlling ownership with the identity of the family and financial institutions.

Finally, this research is expected to be useful for several parties. For academics and further research, this research topic can be a reference that can be analyzed further. For investors, this research can provide information to consider investing decisions. Especially for investors who expect high dividend rates, investors can consider investing in companies whose ownership is not dominated by families. For regulators in Indonesia, this research can be used to evaluate the implementation of shareholder protection laws. Regulators can emphasize the disclosure of company information concerning dividend policies so that all 
shareholders receive accountability information for funds invested in the company. Furthermore, for families that have controlling ownership, this study encourages the company to support shareholder protection by providing detailed information regarding dividend policies and plans for using company profits. Thus, all investors can obtain responsibility related to their investment. For financial institutions that have a controlling ownership, this study encourages active supervision to reduce conflicts of interest between shareholders. For example, by asking the company to publish reports concerning fund allocations periodically. The active involvement of financial institutions in management is expected to increase transparency and company independence.

\section{REFERENCES}

Al-Najjar, B. (2010). Corporate Governance and Institutional Ownership: Evidence from Jordan. Corporate Governance, 10(2), 176-190. https://doi.org/10.1108/14720701011035693

Al-Najjar, B., \& Belghitar, Y. (2014). Do Corporate Governance Mechanisms Affect Cash Dividends? An Empirical Investigation of UK Firms. International Review of Applied Economics, 28(4), 524-538. https://doi.org/10.1080/02692171.2014.884546

Al-Najjar, B., \& Kilincarslan, E. (2016). The Effect of Ownership Structure on Dividend Policy: Evidence from Turkey. Corporate Governance (Bingley), 16(1), 135-161. https://doi.org/10.1108/CG-09-2015-0129

Aluchna, M., Berent, T., \& Kamiński, B. (2019). Dividend Payouts and Shareholder Structure: Evidence from the Warsaw Stock Exchange. Eastern European Economics, $57(3)$,

227-250. https://doi.org/10.1080/00128775.2019.1568196

Barclay, M. J., \& Holderness, C. G. (1989). Private Benefits from Control of Public Corporations. Journal of Financial Economics, 25(2), 371-395. https://doi.org/10.1016/0304-405X(89)90088-3

Baker, H. K. (2009). Dividends and Dividend Policy. Canada: Wiley. https://doi.org/10.1002/9781118258408

Bertrand, M., \& Schoar, A. (2006). The Role of Family in Family Firms. Journal of Economic Perspectives, 20(2), 73-96. https://doi.org/10.1257/jep.20.2.73

Bhojraj, S., \& Sengupta, P. (2003). Effect of Corporate Governance on Bond Ratings and Yields: The Role of Institutional Investors and Outside Directors. Journal of Business, 76(3), 455-475. https://doi.org/10.1086/344114

Bushra, A., \& Mirza, N. (2015). The Determinants of Corporate Dividend Policy in Pakistan. The Lahore Journal of Economics, 20(2), 77-98. https://doi.org/10.35536/lje.2015.v20.i2.a4

Chang, K., Kang, E., \& Li, Y. (2016). Effect of Institutional Ownership on Dividends: An Agency-Theory-Based Analysis. Journal of Business Research, 69(7), 2551-2559. https://doi.org/10.1016/j.jbusres.2015.10.088

Claessens, S., Djankov, S. \& Lang, L. H. P. (2000). The Separation of Ownership and Control in East Asian Corporations. Journal of Financial Economics, 58, 81112. https://doi.org/10.1016/S0304-405X(00)00067-2

Crane, A. D., Michenaud, S., \& Weston, J. P. (2016). The Effect of Institutional 
Ownership on Payout Policy: Evidence from Index Thresholds. Review of Financial Studies, 29(6), 1377-1408. https://doi.org/10.1093/rfs/hhw012

Dallas, G. (2004). Governance and Risk, Analytical Hand Book for Investors, Managers, Directors and Shareholders. New York: McGraw-Hill.

Darmadi, S. (2016). Ownership Concentration, Family Control, and Auditor Choice: Evidence from An Emerging Market. Asian Review of Accounting, 24(1), 1942. https://doi.org/10.1108/ARA-06-2013-0043

Djebali, R. \& Belanes, A. (2015). On the Impact of Family Versus Institutional Blockholders on Dividend Policy. The Journal of Applied Business Research, 31(4). https://doi.org/10.19030/jabr.v31i4.9320

Ducassy, I. \& Montandrau, S. (2015). Corporate Social Performance, Ownership Structure, and Corporate Governance in France. Research in International Business and Finance, 34, 383-396. https://doi.org/10.1016/j.ribaf.2015.02.002

Duran, R. F., Lozano, M. B., \& Yaman, S. (2016). Is Family Control Relevant for Corporate Cash Holding Policy?Journal of Business Finance \& Accounting, 43, 1325-1360. https://doi.org/10.1111/jbfa.12222

Duygun, M., Guney, Y., \& Moin, A. (2018). Dividend policy of Indonesian listed firms: The role of families and the state. Economic Modelling, 75, 336-354. https://doi.org/10.1016/j.econmod.2018.07.007

Easterbrook, B. F. H. (1984). Two Agency-Cost Explanations of Dividends. American Economic Association, 74(4), 650-659.

Faccio, M., \& Lang, L. H. P. (2002). The Ultimate Ownership of Western European Corporations. Journal of Financial Economics, 65, 365-395. https://doi.org/10.1016/S0304-405X(02)00146-0

Gordon, M. J. (1963). Optimal Investment and Financing Policy. The Journal of Finance, 18(2), 264. https://doi.org/10.2307/2977907

Hiebl, M. R. W. (2015). Family Involvement and Organizational Ambidexterity in Later-Generation Family Business. Management Decision, 53(5), 10611082. https://doi.org/10.1108/MD-04-2014-0191

Hoechle, D. (2007). Robust Standard Errors for Panel Regressions with Crosssectional Dependence. Stata Journal, 7(3), 281-312. https://doi.org/10.1177/1536867X0700700301

International Finance Corporation [IFC]. (2018). Indonesia Corporate Governance Manual Second Edition. Retrieved April 12, 2020, from: https://www.ifc.org/wps/wcm/connect/topics ext content/ifc external co rporate site/ifc $+\mathrm{cg} /$ resources/toolkits+and+manuals/indonesia+corporate +governance+manual $\% 2 \mathrm{C}+2 \mathrm{nd}+$ edition.

Isakov, D., \& Weisskopf, J. P. (2015). Pay-Out Policies in Founding Family Firms. Journal of Corporate Finance, 33, 330-344. https://doi.org/10.1016/j.jcorpfin.2015.01.003

Jayanti, I. S. D., \& Puspitasari, A. F. (2017) Struktur Kepemilikan dan Kebijakan Dividen pada Perusahaan Manufaktur di Indonesia. The Indonesian Journal of Applied Business, 1(1), 1-13.

Jensen, M. C. (1986). Agency Costs of Free Cash Flow, Corporate Finance, and Takeovers. The American Economic Review, 76(2), 323-329.

Jensen, M. C., \& Meckling, W. H. (1976). Theory of The Firm: Managerial Behavior, 
Agency Costs and Ownership Structure. Journal of Financial Economics, 3, 305-360. https://doi.org/10.1016/0304-405X(76)90026-X

Kautsar, A. (2019). The Impact of Ownership Structure on Dividend Payout Property and Construction Companies in Indonesia. International Journal of Academic Research in Economics and Management Sciences, 8(1), 66-74. https://doi.org/10.6007/IJAREMS/v8-i1/5555

Kisman, Z. (2013). Factors Influencing Dividend: Pay or Not to Pay on The Indonesia Stock Exchange. International Journal of Innovations in Business, 2(7), 670-715.

La Porta, R., Lopez-de-Silanes, F., \& Shleifer, A. (1999). Corporate Ownership Around the World. The Journal of Finance, 2(2). https://doi.org/10.1111/0022-1082.00115

La Porta R., Lopez-de-Silanes F., Sheilfer, A. \& Vishny, R. W. (2000). Agency Problems and Dividend Policies Around the World. National Bureau of Economic Research, 6594. https://doi.org/10.1111/0022-1082.00199

Lin, Y. R., \& Fu, X. M. (2017). Does Institutional Ownership Influence Firm Performance? Evidence from China. International Review of Economics and Finance, 49, 17-57. https://doi.org/10.1016/j.iref.2017.01.021

Maury, B. (2006). Family Ownership and Firm Performance: Empirical Evidence from Western European Corporations. Journal of Corporate Finance, 12, 321-341. https://doi.org/10.1016/i.jcorpfin.2005.02.002

Madhani, P. (2016). Ownership Concentration, Corporate Governance and Disclosure Practices: A Study of Firms Listed in Bombay Stock Exchange. The IUP Journal of Corporate Governance, 15.

Miko, N. U., \& Kamardin, H. (2015). Ownership Structure and Dividend Policy of Conglomerate Firms in Nigeria. Academic Journal of Interdisciplinary Studies, 4(2), 279-286. https://doi.org/10.5901/ajis.2015.v4n2p279

Moin, A., Guney, Y., \& El Kalak, I. (2019). The Effects of Ownership Structure, SubOptimal Cash Holdings and Investment Inefficiency on Dividend Policy: Evidence from Indonesia. In Review of Quantitative Finance and Accounting, 55, 857-900. https://doi.org/10.1007/s11156-019-00862-z

Mulyani, E., Singh, H., \& Mishra, S. (2016). Dividends, Leverage, and Family Ownership in the Emerging Indonesian Market. Journal of International Financial Markets, Institutions and Money, 43, 16-29. https://doi.org/10.1016/j.intfin.2016.03.004

Musallam, S. R. M., Fauzi, H., \& Nagu, N. (2019). Family, Institutional Investors Ownerships and Corporate Performance: The Case of Indonesia. Social Responsibility Journal, 15(1), 1-10. https://doi.org/10.1108/SRJ-08-2017$\underline{0155}$

Organisation for Economic Co-operation and Development [OECD]. (2017). OECD Survey of Corporate Governance Frameworks in Asia. Retrieved May 22, 2020, from: https://www.oecd.org/corporate/OECD- Survey-CorporateGovernance-Frameworks-Asia.pdf.

Oktaviani, O. \& Desmintari (2016). Pengaruh Profitabilitas, Kebijakan Hutang, dan Dividend Payout Ratio (DPR) terhadap Nilai Perusahaan. Equity, 19(2), 115128. https://doi.org/10.34209/.v19i2.480

Ramli, N. M. (2010). Ownership Structure and Dividend Policy: Evidence from 
Malaysian Companies. International Reviewof Business Research Papers, 6(1), 170-180.

Renneboog, L., \& Szilagyi, P. G. (2015). How Relevant Is Dividend Policy Under Low Shareholder Protection? Journal of International Financial Markets, Institutions and Money, 64. https://doi.org/10.1016/j.intfin.2015.01.006

Reyna, J. M. S. M. (2017). Ownership Structure and Its Effect on Dividend Policy in The Mexican Context. Contaduria y Administracion, 62(4), 1199-1213. https://doi.org/10.1016/i.cya.2015.12.006

Ross, S. A., Westerfield, R. W., Jordan, B. D., Lim, J., \& Tan, R. (2016). Fundamentals of Corporate Finance, Second Edition, Asia Global Edition. New York: McGraw Hill Education.

Rozeff, M. S. (1982). Growth, Beta and Agency Costs as Determinants of Dividend Payout Ratios. The Journal of Financial Research, 5(3), 249-259. https://doi.org/10.1111/j.1475-6803.1982.tb00299.x

Santos, A., Rindra, E., Hidayat, A. A., \& Adelina, Y. E. (2020). Dividend and leverage in Indonesian intergenerational family firms. Jurnal Siasat Bisnis, 24(1), 4358. https://doi.org/10.20885/jsb.vol24.iss1.art4

Scholtens, B. \& Van Wensveen, D. (2000). A Critique on the Theory of Financial Intermediation. Journal of Banking and Finance, 24, 1243-1251. https://doi.org/10.1016/S0378-4266(99)00085-0

Shleifer, A., \& Vishny, R. W. (1986). Large Shareholders and Corporate Control. A Journal of Political Economy, 94(3), 461-488. https://doi.org/10.1086/261385

Shleifer, A. \& Vishny, R. W. (1997). A Survey of Corporate Governance. The Journal of Finance, 52(2). https://doi.org/10.1111/j.1540-6261.1997.tb04820.x

Setia Atmaja, L. (2016). The Impact of Family Control on Dividend Policy: Evidence from Indonesia. International Research Journal of Business Studies, 9(3), 147-156. https://doi.org/10.21632/irjbs.9.3.147-156

Setiawan, D., Bandi, B., Kee Phua, L., \& Trinugroho, I. (2016). Ownership Structure and Dividend Policy in Indonesia. Journal of Asia Business Studies, 10(3), 230-252. https://doi.org/10.1108/JABS-05-2015-0053

Setiyowati, S. W., \& Sari, A. R. (2017). Pengaruh Corporate Governance dan Kinerja Keuangan Terhadap Kebijakan Dividen Pada Perusahaan Manufaktur Yang Listing di Bursa Efek Indonesia Tahun 2014 - 2015. Jurnal AKSI (Akuntansi dan Sistem Informasi), 1(1), 45-57. https://doi.org/10.32486/aksi.v1i1.95

Sinarmayarani, A., \& Suwitho (2016). Pengaruh Kepemilikan Institusional dan Profitabilitas Terhadap Nilai Perusahaan Melalui Kebijakan Dividen. Jurnal Ilmu dan Riset Manajemen, 5(5).

Sindhu, M. I., Hashmi, S. H., \& Ul Haq, E. (2016). Impact of Ownership Structure on Dividend Payout in Pakistani Non-Financial Sector. Cogent Business and Management, $3(1)$,

$0-11$. https://doi.org/10.1080/23311975.2016.1272815

Smirnova, E., Tabriztchi, S., \& Lange, C. (2015). Cash Holdings, Use of Debt and Dividend Structure of Family Firms. American Journal of Economics and Business Administration, 7(1), 1-10. https://doi.org/10.3844/ajebasp.2015.1.10 
Subramaniam, V. (2018). Family Ownership and Dividend Policy: Empirical Evidence from Malaysia. International Journal of Business and Management, 13(5), 112. https://doi.org/10.5539/ijbm.v13n5p112

Thomsen, S. \& Pedersen, T. (2000). Ownership Structure and Economic Performance in the Largest European Companies. Strategic Management Journal, 21, 689-705. $\quad$ https://doi.org/10.1002/(SICI)10970266(200006)21:6<689::AID-SMJ115>3.0.CO;2-Y

Truong, T., \& Heaney, R. (2007). Largest Shareholder and Dividend Policy Around The World. The Quarterly Review of Economics and Finance, 47(5), 667687. https://doi.org/10.1016/j.qref.2007.09.002

UU. (2008). Undang Undang No 40 Tahun 2007 tentang Perseroan Terbatas. Jakarta: Sekretariat Negara.

Vandemaele, S., \& Vancauteren, M. (2013). Nonfinancial Goals, Governance, and Dividend Payout in Private. https://doi.org/10.1111/jsbm.12063

Family Firms. Journal of Small Business Management, 53(1), 166-182.

Velury, U., \& Jenkins, D. S. (2006). Institutional Ownership and The Quality of Earnings. Journal of Business Research, 59(9), 1043-1051. https://doi.org/10.1016/j.jbusres.2006.05.001

Wardhana, L. I., \& Tandelilin, E. (2018). Do We Need A Mandatory Dividend Regulation? The Case of Indonesian Capital Market. Gajah Mada International Journal of Business, 20(1), 33-58. https://doi.org/10.22146/gamaijb.25055

Warsini, S. (2013). Konsentrasi Kepemilikan Keluarga, Independensi Dewan Komisaris dan Manajemen Laba. Prosiding Simposium Nasional Akuntansi Vokasi ke-2, 17-18.

Xu, N., Yuan, G., Jiang, X., \& Chan, K. C. (2015). Founder's Political Connections, Second Generation Involvement and Family Firm Performance: Evidence from China. Journal of Corporate Finance, 33, 243-259. https://doi.org/10.1016/i.jcorpfin.2015.01.004

Zeckhauser, R. J. \& Pound J. (1990). Are Large Shareholder Effective Monitors? An Investigation of Share Ownership and Corporate Performance. Asymmetric Information, Corporate Finance and Investment, 149- 18. 